\title{
How Fast Does the Steppe Eagle Population Decline? Survey Results from Eilat, Israel
}

\section{КАК БЫСТРО СНИЖАЕТСЯ ЧИСЛЕННОСТЬ ПОПУЛЯЦИИ СТЕПНОГО ОРЛА? РЕЗУЛЬТАТЫ НАБЛЮДЕНИЙ В ЭЙЛАТЕ, ИЗРАИЛЬ}

\author{
Weiss N. (The Israeli Ornithological Center, The Society for the Protection of Nature in \\ Israel, Tel Aviv; International Birding and Research Center, Eilat, Israel) \\ Haviv E., Alon D., Perlman Yo. (The Israeli Ornithological Center, The Society for the \\ Protection of Nature in Israel, Tel Aviv, Israel) \\ Schäckermann J. (Dead Sea and Arava Science Center, Southern Arava R\&D, DN Chevel \\ Eilot, Israel) \\ Вейсс Н. (Израильский орнитологический центр, Общество защиты природы \\ Израиля, Тель-Авив; Международный центр наблюдения и изучения птиц, Эйлат, \\ Израиль) \\ Хавив Е., Алон Д., Перлман Й. (Израильский орнитологический центр, Общество \\ защиты природы Израиля, Тель-Авив, Израиль) \\ Шэкерманн Дж. (Научный центр Мёртвого моря и Аравии, Южная Арава Р\&Д, Чевел \\ Эйлат, Израиль)
}

\section{Contact:}

Noam Weiss

The Israeli

Ornithological Center

The Society for the

Protection of Nature in

Israel, Hanegev, 2,

Tel Aviv, Israel

The International

Birding and Research

Center,

P.O. Box: 774

Eilat, Israel

noamw@spni.org.il

Eli Haviv

The Israeli

Ornithological Center,

The Society for the

Protection of Nature in

Israel,

Hanegev, 2,

Tel Aviv, Israel

elih@spni.org.il

Dan Alon

The Israeli

Ornithological Center,

The Society for the

Protection of Nature in

Israel,

Hanegev, 2,

Tel Aviv, Israel

dan@spni.org.il

\section{Резюме}

Мировая популяция степного орла (Aquila nipalensis) имеет статус угрожаемой и быстро теряет численность по всему ареау. Эйлат, расположенный в южном Израиле - это так называемое "бутылочное горлышко" на пути весенней миграции этого вида из Асрики. Мы провели серию полевых исследований с 2015 по 2018 гг., ведя подсчёт пролетаюших степных орлов, и собирая данные об их возрасте. Полученные данные мы сравнили с аналогичными, собранными за 4 весенних сезона в промежутке межху 1977 и 1988 гг. Мы не выявили Аостоверных различий межАу Авумя выборками по количеству степных орлов, проходяших нац Эйлатом на весенней миграции. Это означает, что зимовки степного орла в Африке и его пути миграции в Асрику и обратно относительно безопасны. Мы также обнаружили, что 75\% пролетаюших орлов - это взрослые особи, и что их основной пролёт приходится на третью неделю февраля. Эта информация способствует улучшению мер по охране вида.

Кмючевые слова: пернатые хишники, хишные птицы, степной орёл, Aquila nipalensis, миграция.

Поступияа в редакцию: 16.11 .2018 г. Принята к публикации: 20.12.2018 г.

\section{Abstract}

The world Steppe Eagle (Aquila nipalensis) population is considered Endangered and is rapidly declining across most of it range. Eilat, in southern Israel, is a bottleneck for this species on its migration route from Africa in spring. We conducted a series of surveys, counting the passing Steppe Eagles in springs 2015 to 2018 and collecting data about the age of the passing birds. We then compared our data with the Steppe Eagle data collected during four springs between 1977 and 1988 . We did not find a significant decline in Steppe Eagle numbers passing Eilat on their spring migration between the two data sets. This implies that the overwintering sites in Africa and the migration flyway to and from Africa are relatively safe for the Steppe Eagles. We furthermore found that $75 \%$ of the eagles passing are adults and that their main passage is during the third week of February. This information helps to adjust conservation efforts.

Keywords: birds of prey, raptors, Steppe Eagle, Aquila nipalensis, migration.

Received: 16/11/2018. Accepted: 20/12/2018.

DOI: $10.19074 / 1814-8654-2019-38-59-67$

\section{Введение}

Степной орёл (Aquila nipalensis) - вил, исчезаюший глобаиьно и находяшийся на грани исчезновения в Европе (Birdlife International, 2017). Популяция претерпевает быстрое снижение численности на большей части ареала из-за уничтожения местообитаний, столкновений с АЭП и поражения электротоком, браконьер-

\section{Introduction}

The Steppe Eagle (Aquila nipalensis) is globally Endangered and Critically Endangered in Europe (Birdlife International, 2017). The population is undergoing a rapid decline across much of its range, due to land-use changes, power line collisions and electrocutions, poaching, and disturbance (Birdlife International, 2017; Karyakin, 2013; Kar- 
Yoav Perlman

The Israeli

Ornithological Center

The Society for the

Protection of Nature in Israel,

Hanegev, 2

Tel Aviv, Israel

yoav.perlman@

gmail.com

Jessica Schäckermann Dead Sea and Arava

Science Center,

Southern Arava R\&D,

DN Chevel Eilot,

8882000, Israel

jessica@adssc.org ством и беспокойством со стороны человека (Birdlife International, 2017; Karyakin, 2013; Karyakin, 2018; Goroshko, 2018). Сообшения из мест зимовок этого вида в Индии и Непале указывают на гибель степных орлов, кормяшихся на останках животных, содержаших следы обезболиваюших среАств, таких, как микиосенак и его заменители (Oaks, 2004; Borha, Vyas, 2018). Недавнее отслеживание степных орлов показало, что европейская и казахстанская популяции используют обе основные зимовки, мигрируя и в Асрику, и в Южную Азию (Karyakin et al., 2018). Аıя того, чтобы подтвердить описанные негативные тенденции, оценить уровень снижения численности популяции и понять, гле именно расположены главные зоны риска (в гнездовом ареале, на зимовках, или на путях пролёта), исследователи веАут подсчёт орлов в основных миграционных "бутылочных горлышках" (Kerlinger, 1989). И всё же, данных из узких мест на пути миграции степных орлов очень мало.

Большая часть популяции степного орла, зимуюшего в Африке, "просачивается" через бутылочное горлышко в Эйлатских горах во время весеннего пролёта в северном направлении (Meyburg et al., 2003; Shirihai, Christie, 1992). Израильский орнитологический центр Обшества охраны природы Израиля (SPNI) при сотрудничестве с Международным центром исследований и наблюдения за птицами в Эйлате (IBRCE) проводил нерегулярные наблюдения в Эйлате с 1977 по 1998 гг. Эти наблюдения выявили, что миграционный путь через Эйлат - вероятно самый загруженный миграционный коридор, используемый степным орлом весной - в среднем за сезон здесь проходило 19643 55055 ос. $( \pm S D)$, от 7679 so 75053 oc. (Shirihai et al., 2000; Zduniak et al., 2010). Аругие учёты степных орлов на миграции через «буты-

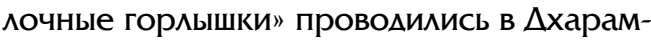
сале в Гималаях, Индия (от 5900 до 11000 особей в 2001-2002 гг.; Besten, 2004) и на обзорной точке Тулахарка, Непал (от 6166 Ао 8684 особей в 2012-2014 гг.; Subedi, 2015). Считается, что на обзорных точках в Индии и Непале ведётся мониторинг восточных популяций степного орла из Монголии и Ааурии, на их пути к зимовочным местам в Индии и Юго-Восточной Азии (Subedi, 2015). Опубликованные Аанные о подсчётах орлов на миграции через Баб-эль-Мандебский пролив межлу южной частью Аравийского полуострова и полуострова Сомали отсутствуют.

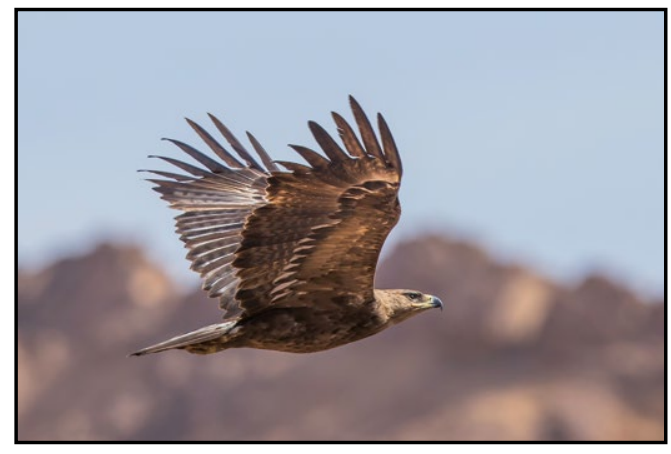

Степной орёл (Aquila nipalensis). Эйлат, Израиль, март 2015 г. Фото Х. Ширихаи.

Steppe Eagle (Aquila nipalensis). Eilat, Israel, March 2015. Photo by H. Shirihai.

yakin, 2018; Goroshko, 2018). Reports from wintering areas in India and Nepal indicate death of Steppe Eagles feeding on carcasses with remains of painkillers such as diclofenac and its substitutes (Oaks, 2004; Borha, Vyas, 2018). Recent Steppe Eagle tagging results show that the European and Kazakh populations of Steppe Eagles migrate to both main wintering areas in Africa and Southern Asia (Karyakin et al., 2018). In order to verify the described negative trend, to assess the rate of population decline and to understand where the main problem is located (in breeding grounds, wintering regions or along the migration routes), researchers count eagles in the main migration bottlenecks (Kerlinger, 1989). Nevertheless, data from migration bottlenecks of Steppe Eagles are scarce.

A large portion of the Steppe Eagle's population which overwinters in Africa funnel through the bottleneck of Eilat Mountains on their northbound spring migration (Meyburg et al., 2003; Shirihai, Christie, 1992). The Israeli Ornithological Center of the Society for the Protection of Nature in Israel (SPNI), with the cooperation of the International Birding and Research Center Eilat (IBRCE) conducted surveys in Eilat sporadically from 1977 to 1998. These revealed that the route through Eilat is probably the busiest corridor serving Steppe Eagles in spring (mean per season \pm $S D=19,643 \pm 5055$, range $=7,679$ to 75,053 ; Shirihai et al., 2000; Zduniak et al., 2010). Other migration counts conducted in other bottlenecks surveyed the Steppe Eagles at Dharamsala, in Himalayan India (5,900 to 11,000 in 2001-2002; Besten, 2004) and in Thoolakharka watchpoint, Nepal $(6,166$ to 8,684 in 2012-2014; Subedi, 2015). The Indian and Nepalese count sites are believed to observe the eastern populations of eagles 
Учитывая тяжёлое состояние всемирной популяции степного орла (Karyakin, 2018), оставалось неясным, произошли ки изменения в численности пролетаюших через Эйлат особей со времени последних учётов в 1980-х гг. Чтобы осознать текушую ситуацию с популяцией степного орла, мигрируюшего через Эйлат, мы изучаии его пролёт в течение четырёх последовательных лет. Методика подсчёта использовамась та же, что была описана в работе X. Ширихаи и $\Delta$. Христи (Shirihai, Christie, 1992), чтобы наши методы были сопоставимы с методами учёта 1977-1988 гг. Целями нашего исследования было: описать популяционные тренды за 4 года наблюдений (численность стабильна, снижается или растёт), сравнить результаты наших учётов с Аанными 1980-х гг., чтобы выявить Аолговременные популяционные тренды и оценить возрастной состав (взрослые, неполовозрелые) степных орлов, летяших через Эйлат.

\section{Методы}

\section{Учёты степных орлов}

Учёты степных орлов в прошлом проводимись близ Эйлата межАу 1977 и 1998 гг. Но методики и затраченные усилия не были одинаковы в разные годы. В 1985 и 1986 гг. целью являлся учёт как можно большего числа особей, мия чего обустраивалось Ао семи учётных станций на пике пролёта и устраивались "забеги" следом за потоком пролетаюших хищных птиц, вплоть Ао 100 км к северу от Эйлата. Учёты 1977, 1983, 1987 и 1988 гг., по-видимому, использоваяи анамогичные методы и усилия, и в эти гоАЫ Учёты провоАИАись от 83 Ао 107 Аней в году (Shirihai, Christie, 1992). Метод, который мы использоваии в 20152018 гг., был взят из статьи Ширихай (Shirihai et al., 2000) и очевидно соответствоваи методу, используемому в те годы. Мы использовали те же самые две стационарные учётные станции и располагали наблюАателей по двое на каждой из станций. ЕАинственным размичием, обнаруженным нами между методиками, использованными в 1980-е и 2010-е гг., была дата начала наблюдений: в 1980-х гг. они начинаиись 15 февраля, а в 2010-х - 1 февраля. Чтобы сравнить Аанные 1980-х с 2010-ми гг. и провести Аинию популяционного тренда мля степного орла, метяшего через Эйлат, мы использовали Аанные учётов мишь тех годов, в которые применялись методики, идентичные нашим (1977, 1983, 1987 и 1988 гг.). Наши учёты проводились четыре года подрял, с 2015 по 2018 гг., в период from Mongolian and Daurian origin on their way to winter in India and South East Asia (Subedi, 2015). Published migration counts from the bottleneck of Bab El-Mandeb, between southern Arabia and the Horn of Africa, are missing.

Following the grave condition of the global Steppe Eagle's population (Karyakin, 2018), it was unclear whether numbers passing through Eilat have changed since the last counts in the 1980s. In order to understand the current situation of the eagle population passing the Eilat bottleneck, we conducted a migration survey during four consecutive years. We used the count methods described by Shirihai, Christie (1992), to match the methods used for the counts between 1977 and 1988. Our study goals were to describe the population trends within our four years of counting (stability, decline or increase), to compare our counting results with the 1980s data to see if there is a long term population trend, and to survey the age composition (adult, non-adult) of Steppe Eagles passing Eilat.

\section{Methods \\ Steppe Eagle counts}

Steppe Eagle counts were conducted near Eilat in the past between 1977 and 1998. However, the count methods and effort were not consistent among the years. While in 1985 and 1986 the counts' goal was to monitor as many raptors as possible, including the opening of up to seven count stations in peak days and "running" after the stream of raptors, even to a distance of $100 \mathrm{~km}$ north of Eilat, the counts in 1977, 1983, 1987 and 1988 appeared to have employed similar methods and effort, with 83 to 107 count days per year (Shirihai, Christie, 1992). The method we used between 2015 and 2018 was according to Shirihai et al., 2000 and appeared to match the method used in these years. We used the same two stationary count stations and allocated two observers to each count station. The only difference we found in the methods used (1980s compared to 2010s) was the start date of the survey, which was the $15^{\text {th }}$ of February (1980s) rather than the $1^{\text {st }}$ of February (2010s). In order to compare the 1980s' data to the 2010s' data and to draw a trendline of the population of the Steppe Eagles who pass in Eilat, we only used the data of years that were collected using similar methods (1977, 1983, 1987 and $1988)$. We conducted the raptor counts in four consecutive years from 2015 to 2018 , between the $1^{\text {st }}$ of February and the $15^{\text {th }}$ of 
Рис. 1. Расположение двух наблюдательных точек (HMS - точка на высокой горе и LMS - точка на низкой горе), использованных в 1977, 1983, 1987, 1988 и 2015-2018 гг. в Эйлатских горах. Условные обозначения: A - учётный трансект; большими стрелками указано наиболее частое направление пролёта степного орла (Aquila nipalensis).

Fig. 1. The location of the two count stations (HMS - high mountain station and LMS - low mountain station) used in the years 1977, 1983, 1987, 1988 and 2015-2018 in Eilat Mountains. Labels: A - the transect count line; the most common direction of Steppe Eagle's (Aquila nipalensis) passage in big arrows.

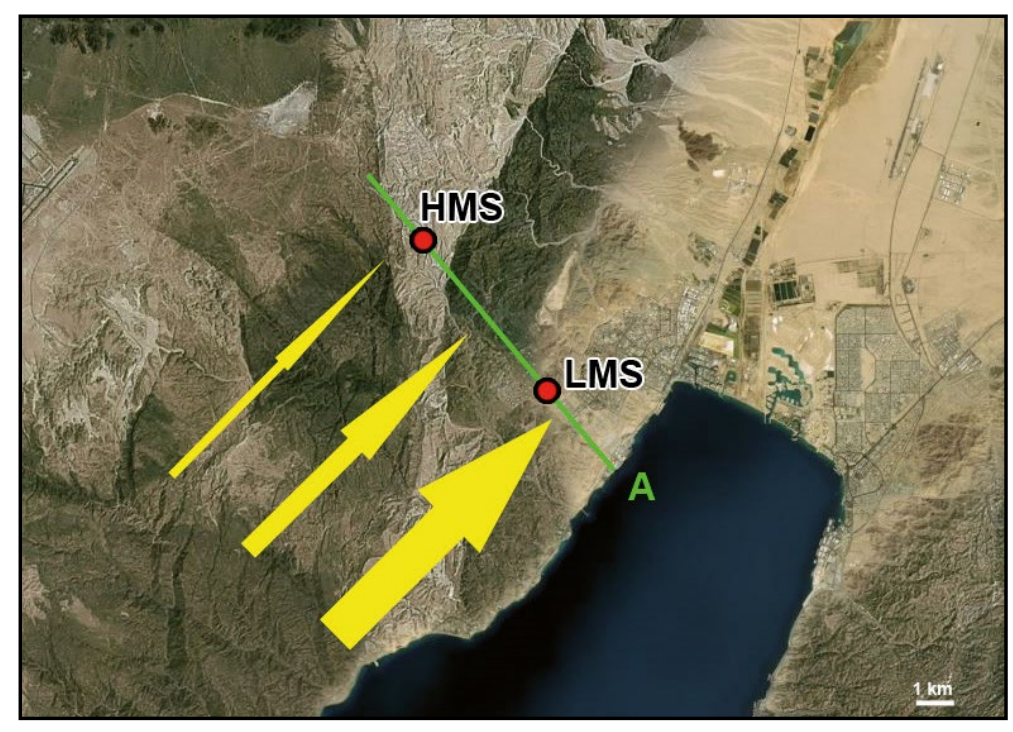

между 1 феврамя и 15 мая (кроме 2018 г., когАа учёты были окончены 10 апреля, поскольку более 97\% степных орлов в 20152017 гг. пролетаяи как раз до 10 апреля). Итого в 2015, 2016 и 2017 гг. было проведено 104 ння учёта, а в 2018 г. - 69 нней. Были укомплектованы две наблюдательные станции: "Низкая гора" в западных окрестностях города Эйлат в точке с координатами N 29,325411 $1^{\circ}$ Е 34,553513 ${ }^{\circ}$ на высоте 208 м, и "Высокая гора" на горе Йорам с координатами N 29,34591 $1^{\circ}$ E 34,538312 на высоте 571 м. Обе станции были ориентированы на юго-запах. Расстояние между станциями составляло 5 км. Большинство орлов в регионе пролетают под прямым угАом к Аинии, соеАиняюшей станции, что позволяет вести учёты очень эффективно (рис. 1). Ава обученных наблюдателя на каждой станции проводики систематический учёт всех хишных птиц ежедневно, с рассвета $А$ заката, используя высококачественные бинокии (ZEISS Victory SF $10 \times 42$ или аналогичные) и зрительную трубу (ZEISS Gavia 30-60 zoom lens или аналогичную). Чтобы искиючить Аублирование при учётах, станции подмерживаяи связь Аруг с Аругом по рации и телесону. Аия описания возрастной структуры популяции орлов, летяших наА Эйлатом, мы предприняли попытку оценить возраст как можно большего числа птиц. Аия этого использоваяась методика, описанная у $\Delta$. Форсмана (Forsman, 1999), мия определения возраста птицы по состоянию оперения и стадии миньки. Аанные учёта вводимись в планшетные компьютеры сразу же, в режиме реаиьного времени, с помошью специамьной программы ммя учёта миграций (Trektellen ${ }^{34}$ ), которая используется и
May (in 2018 only until the $10^{\text {th }}$ of April as more than $97 \%$ of the Steppe Eagles passed in 2015-2017 before the $10^{\text {th }}$ of April). We conducted 104 count days in each of the years 2015, 2016 and 2017 and 69 days in 2018. Two count stations were manned: "Low Mountain" on the western outskirts of the town of Eilat at N 29,32541 $1^{\circ}$ E $34,553513^{\circ}$ with an elevation of $208 \mathrm{~m}$, and "High Mountain" at Mount Yehoram,

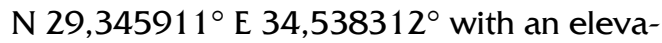
tion of $571 \mathrm{~m}$. Both stations face southwest. The distance between the two stations is 5 $\mathrm{km}$. Most eagles in this region pass perpendicularly to the straight line that connects the two stations, allowing efficient counts (fig. 1). Two trained birders per each station systematically counted all raptors between sunrise and sunset every day, using quality binoculars (ZEISS Victory SF $10 \times 42$ or similar) and telescope (ZEISS Gavia 30-60 zoom lens or similar). To exclude double counts, radio and phone contact was made in real time between the stations. In order to describe the population age structure of the eagles who pass in Eilat, we dedicated an effort to age as many eagles as possible. We used the methods described in Forsman (1999) to determine the age of the birds by plumage and molt. All data was typed to tablet computers in the field in real time using migration count software $\left(\right.$ Trektellen $\left.{ }^{34}\right)$, used by other raptor counts in Europe. Because the counts of 2015-2018 did not exhibit normal distribution of data from the $15^{\text {th }}$ of February but did from the $1^{\text {st }}$ of February, and the average proportion of the eagles' passage between the $1^{\text {st }}$ of February and the $14^{\text {th }}$ of February was $9.95 \%$, we added $9.95 \%$ to the number of eagles 
в Аругих учётах хишных птиц в Европе. Поскольку распределение результатов 2015-2018 гг. отличалось от нормального в период с 15 февраяя, но не отличамось в период с 1 февраля, и средняя доля орлов, пролетавших с 1 по 14 февраия составила 9,95\%, то мы добавили эти же 9,95\% к числу орлов, учтённых в 1977-1988 гг., предполагая, что распределение орлов на пролёте в 1977-1988 гг. было аналогично 2015-2018 гг.

\section{Обработка данных}

Наш анализ был нацелен на проверку того, что различие межАу учётами в 1980-х гг. ( $n=4$ межау 1977 и 1988 гг.) и в 2010-х гг. ( $n=4$ межАу 2015 и 2018 гг.) было больше, чем разброс внутри этих групп, при помоши Т-критерия Стьюдента. Прежле чем проанамизировать данные с помошью Т-теста, мы протестироваии нормамьность их распределения с помошью критерия Шапиро-Уилка ( $>>0.05)$. Попумяционный тренА с 2015 по 2018 год был оценён с помошью минейной регрессии. $\triangle \wedge я$ анализа Аанных был использован SPSS version 23 (IBM Corp., 2015).

\section{Результаты}

Среднее число мигрируюших степных орлов с 2015 г. по 2018 г. составило 15192 ос. в год. Мы не обнаружили никакого явного популяционного тренда в течение 4 лет наблюдений, т.е. популяция стабильна (Linear regression test, $P=0,95$, $R=0,045)$ (рис. 2).

Среднее число степных орлов на пролёте межАу 1977 и 1988 гг. составляло 17829 ос., а с учётом предположительного числа неучтённых особей, пролетевших в первой половине февраля - 19540 орАов (SD=4943,7; рис. 3).

Мы не обнаружили достоверного снижения численности степных орлов на

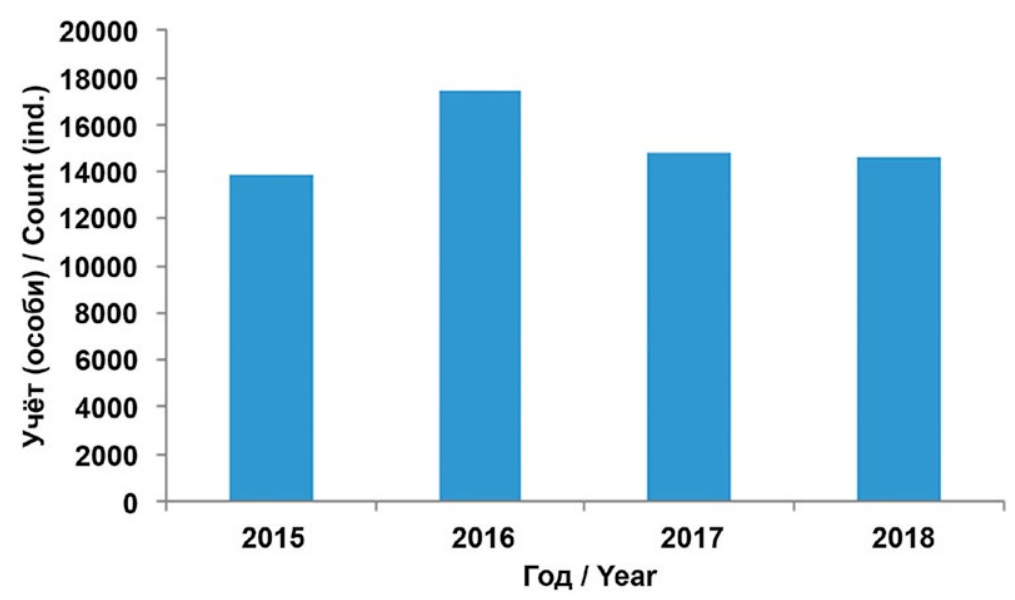

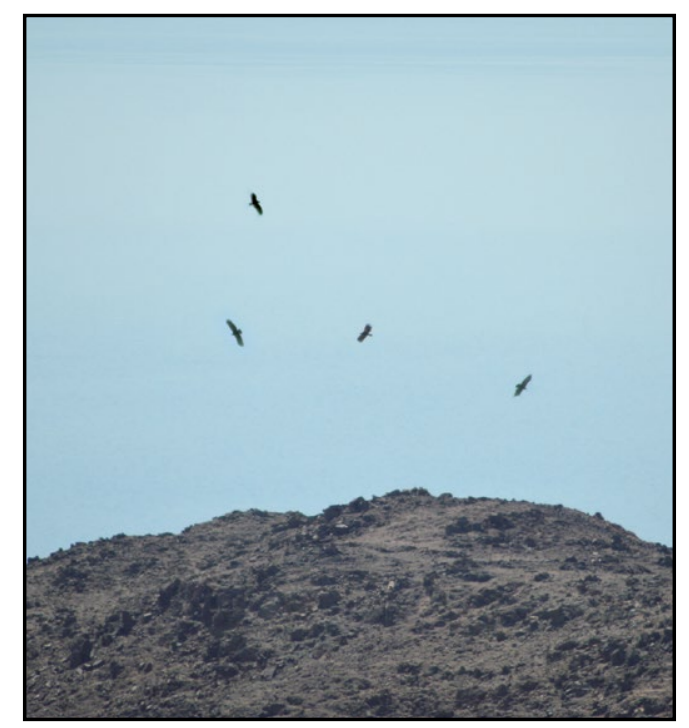

Степные орлы (Aquila nipalensis) нац Эйлатскими горами во время весенней миграции. Фото И. Карякина.

Steppe Eagles (Aquila nipalensis) over the Eilat Mountains during spring migration. Photo by I. Karyakin.

counted in the years 1977-1988 assuming that the eagle passage distribution in 19771988 was similar to 2015-2018.

\section{Data analysis}

Our analysis sought to test whether the variation between 1980s ( $n=4$ between 1977 and 1988) and 2010s ( $n=4$ between 2015 and 2018) was greater than variation within these groups, using IndependentSamples T Test. First, we tested our data for normal distribution using the Shapiro - Wilk test $(p>0.05)$, before analyzing it with the T-Test. To find the population trend in the years 2015 to 2018, we conducted a Linear Regression test. Data analysis was done using SPSS version 23 (IBM Corp., 2015).

\section{Results}

The mean count of Steppe Eagles in the years 2015 to 2018 was 15,192 . The relatively low standard deviation, 1,553.7, highlights the relative effectiveness of the counting method. We did not find any clear population trend within the four survey

Рис. 2. Количество особей степных орлов, учтённых в Эйлате во время весеннего пролёта в 2015-2018 гг.

Fig. 2. Numbers of Steppe Eagles counted in Eilat's raptor count by year in springs 2015-2018. 

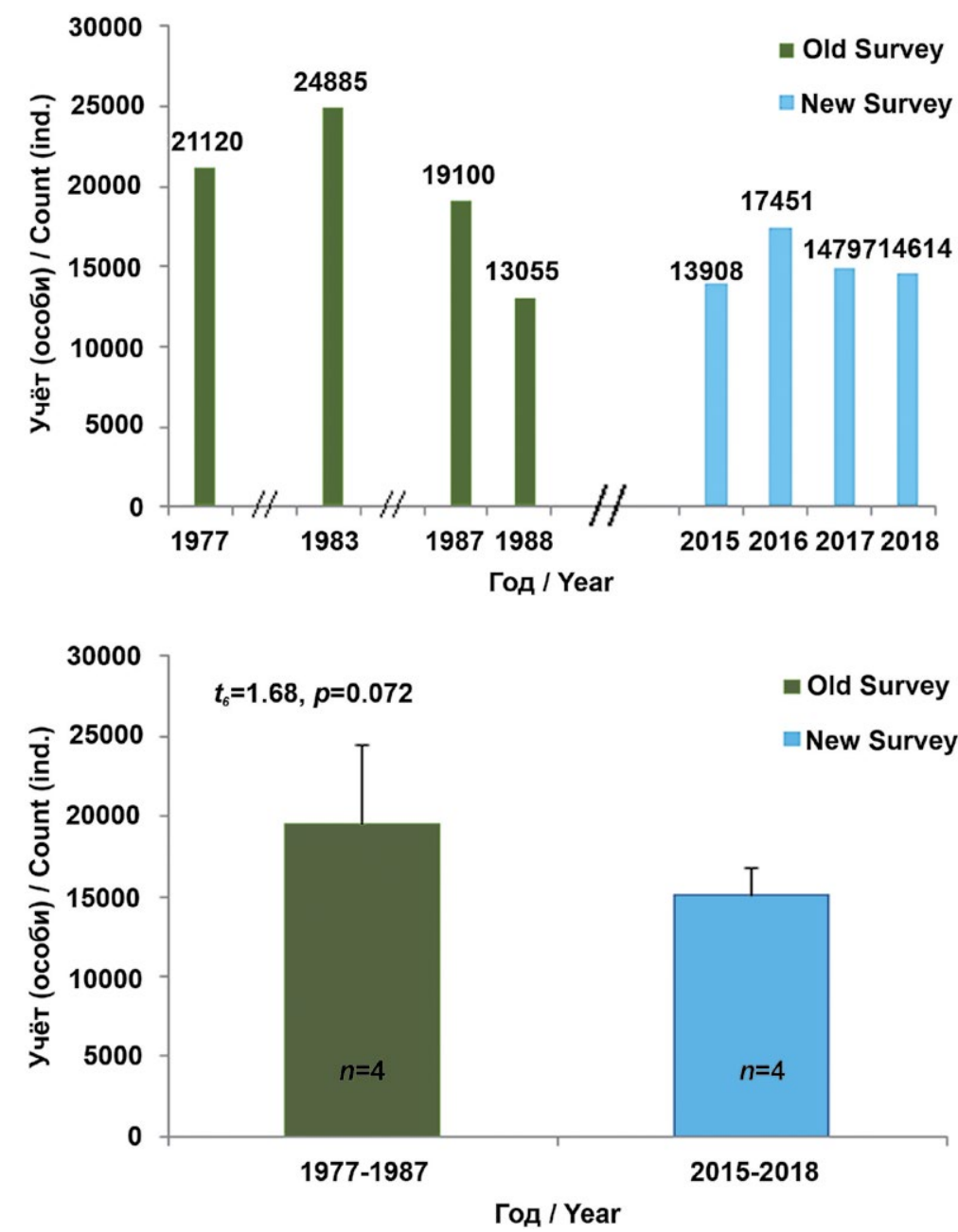

Рис. 4. Среднее число степных орлов по весенним учётам 1977, 1983, 1987 и 1988 гг. (мевый столбец) и среАнее по 2015-2018 гг. (правый столбец).

Fig. 4. Mean Steppe Eagle counts in Eilat by year in springs 1977 , 1983, 1987, 1988 in left, and springs 2015-2018 in right. пролёте в 2010-х гг. по сравнению с 1980-ми гг. ( $p=0,072$; рис. 4$)$, но согласно А. Хакшоу и А. Кирквуду (Hackshaw, Kirkwood, 2011), результаты могут быть оценены как "близкие к достоверным".

Фенология пролёта степного орла через Эйлат с 2015 по 2018 гг. показама, что 95\% орлов пролетали в промежутке межАу 10 февраля и 31 марта. Аалее, 50\% пролетами между 23 февраяя и 6 марта, а 33\% - между 1 и 7 марта. Пик пролёта приходился на первые три дня марта (рис. 5), а

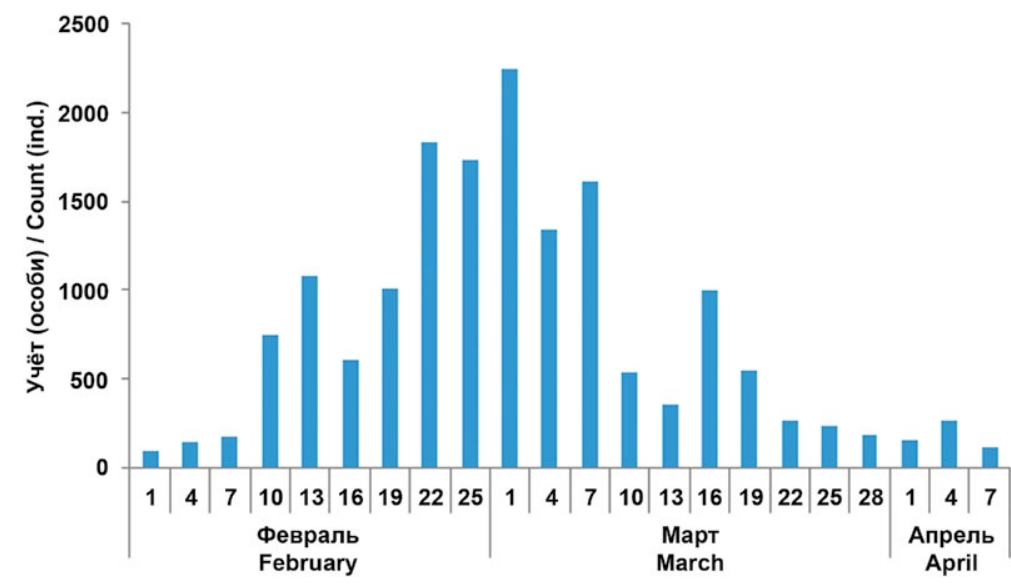

Рис. 3. Число степных орлов, учтённых в Эйлате на весеннем пролёте в 1977, 1983, 1987, 1988 гг. (левая часть диаграммы) и 2015-2018 гг. (правая часть Аиаграммы).

Fig. 3. Numbers of Steppe Eagles counted in Eilat's raptor survey by year in springs 1977, 1983, 1987, 1988 in left columns and springs 2015-2018 in right columns.

years other than stability (Linear regression test, $P=0.95, R=0.045$ ) (fig. 2 ).

While the Steppe Eagle's count per year between 2015 and 2018 is 15,192 (standard deviance 1,553.7), the average count between 1977 and 1988, was 17,829, and with the addition of the estimated passage that was not counted during the first half of February - 19,540 (SD=4943.7; fig. 3).

We did not find a significant decline from the 1980's to the 2010's current survey ( $p=0.072$; fig. 4), but according to Hackshaw, Kirkwood, 2011, the data can be described as "borderline significant".

Phenology of Steppe Eagle passage in Eilat between 2015 and 2018 showed that 95\% of the eagles passed between the $10^{\text {th }}$ of February and the $31^{\text {st }}$ of March. Furthermore, $50 \%$ passed between the $23^{\text {rd }}$ of February and the $6^{\text {th }}$ of March and 33\% between the $1^{\text {st }}$ and $7^{\text {th }}$ of March. The peak of the passage was around the first three days of March (fig. 5). Peak passage of adults occurred during the third week of February. Almost no adult eagles were recorded in March (fig. 6).

In total, $75 \%$ of the eagles that we aged were adults. Our data displays that in February $95 \%$ of the aged individuals were adults while in March, only $40 \%$ were adults, demonstrating the earlier migration of adults that pass in a narrow time window during the last two weeks of February. Passage of adults stopped in the last week of March (fig. 7).

\section{Discussion}

The world population of Steppe Eagles including the populations of European Russia and Kazakhstan, which use the Eilat bottleneck, continue to decline sharply (Karyakin, 2013; Birdlife International, 2017). B. Meyburg (Meyburg et al., 2003) furthermore

Рис. 5. Фенология миграции степных орлов в Эйлате, 2015-2018 гг

Fig. 5. Steppe Eagle migration phenology in Eilat, 2015-2018. 


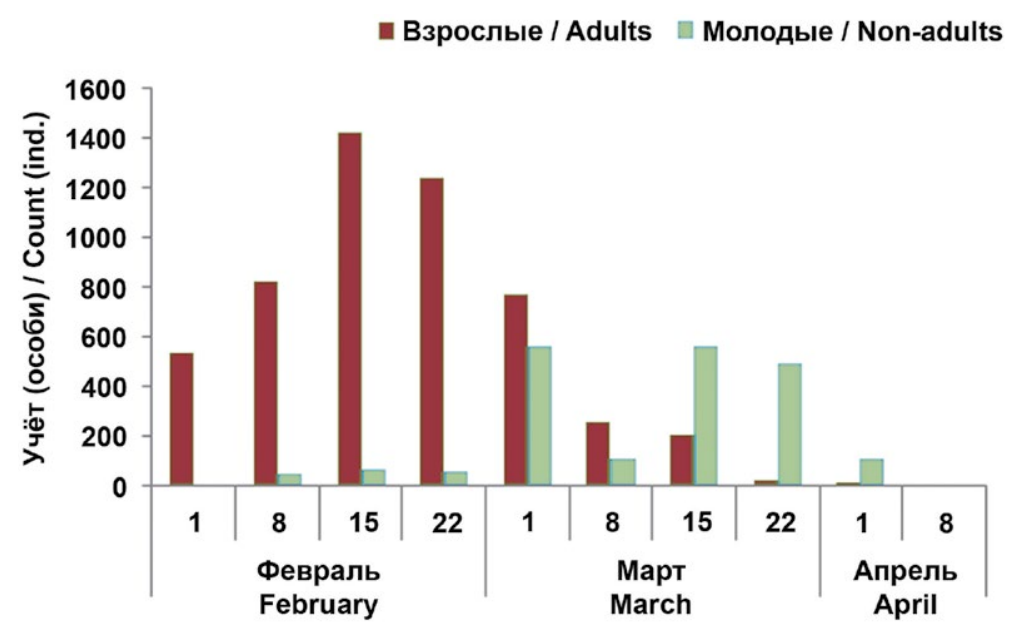

пиковый пролёт взрослых особей происходил в течение третьей недели февраля. В марте взрослые особи практически не регистрировамись (рис. 6).

Из всех орлов, мля которых была установлена возрастная группа, 75\% оказамись взрослыми особями. Наши манные показывают, что в февраме 95\% всех особей с установленной возрастной группой были взрослые особи, а в марте взрослых птиц было лишь 40\%. Это говорит о более ранней миграции взрослых птиц, которые пролетают в более узком временном окне в течение двух последних недель февра^я. Пролёт взрослых особей оканчивается в последнюю неделю марта (рис. 7).

\section{Обсужмение}

Мировая популяция степного орла, вкАючая популяции Европейской части России и Казахстана, которые используют эйлатское "бутылочное горлышко", проАолжает быстро сокрашаться (Karyakin, 2013; Birdlife International, 2017). К тому же, Б. Мейбург (Meyburg et al., 2003) спрогнозировая, что относительный спах числа степных орлов на учётах в Эйлате

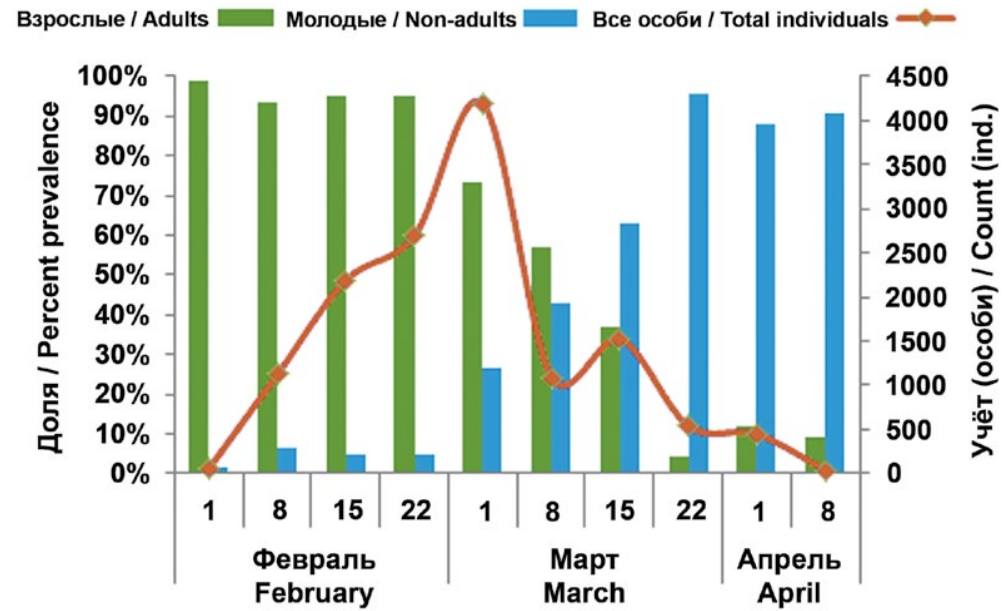

Рис. 6. Временной график прохождения орлов разного возраста через Эйлат на весенней миграции в 2015-2018 гг.

Fig. 6. The timing of passage of Steppe Eagles in Eilat, 2015-2018, by age.

predicted a relative decline in Steppe Eagle numbers counted in Eilat due to an increase of overwintering Steppe Eagles in Arabia, rather than overall population decline (Meyburg et al., 2003; McGrady, Meyburg, 2018).

Even though the average bird count numbers for the 1980s (1977-1988; 19,540 counted birds) were higher than the numbers for the 2010s (2015-2018; 15,192 birds), we did not find a significant decline in numbers of Steppe Eagles passing through the Eilat bottleneck in spring. Therefore, the findings of Karyakin $(2013,2018)$ and IUCN (Birdlife international, 2017) stating that the global Steppe Eagle numbers are declining and that their population is endangered, is not reflected in the data concerning the Steppe Eagles passing through Eilat. The high differences in counted numbers of Steppe Eagles between the years of 1977 to 1988 and the resulting rather high standard deviance of $4,943.7$ for the early counts could have resulted from the distribution of four count years over 12 years.

Our results indicate that Africa and probably the flyways to and from it are relatively safe for eagles. Additional years of monitoring may show a clearer picture and give a better perspective of the Steppe Eagles' population trend. We plan to repeat another four seasons of monitoring, starting in 2024, using the same protocol used for this current study.

We found that $75 \%$ of the eagles passing in Eilat in our 2010's study years were adults who probably have higher survival rates, while the majority of eagles overwintering in other sites north of Eilat or in Arabia are young (McGrady, Meyburg, 2018; Meyburg et al., 2003) and therefore might show a sharper decline than adult birds, as predicted by Meyburg et al., 2003.

Рис. 7. Процентное соотношение взросиых и неполовозрелых степных орлов, летяших через Эйлат в 2015-2018 гг., по неделям, а также обшее число особей степного орла по неделям (Аиния).

Fig. 7. The percentage of adult and non-adult Steppe Eagles passing through Eilat each week in 20152018 , and the total passage of Steppe Eagles by week (line). 
будет связан скорее с увеличением числа зимуюших степных орлов на Аравийском полуострове, чем с обшей потерей численности популяции (Meyburg et al., 2003; McGrady, Meyburg, 2018).

$\triangle$ аже несмотря на то, что среднее чис^о учтённых степных орлов в 1980-х гг. (1977-1988; 19540 учтённых орлов) было выше, чем в 2010-х гг. (2015-2018; 15192 орлов), мы не выявили достоверного снижения в численности степных орлов, летяших через Эйлат весной. Таким образом, данные И.В. Карякина (2013, 2018) и МСОП (Birdlife international, 2017), указываюшие на то, что численность мировой популяции степного орла пахает и что популяция находится под угрозой исчезновения, не находят отражения в результатах изучения пролёта степных орлов наА Эйлатом. Сушественная разница в учтённом числе орлов с 1977 по 1988 гг., выразившаяся в высоком значении стандартного откионения $(S D=4943,7)$, вероятно может быть связана с распределением в Авенаццатилетнем периоде тех 4-х лет, в которые проводились учёты.

Наши результаты показывают, что Асррика и, возможно, пути миграции туда и обратно относительно безопасны мия орлов. Ешё несколько лет наблюдений дадут более чёткую картину и лучшее представление о популяционных трендах у степного орла. Мы планируем повторить работу по учёту еше в течение 4 сезонов, начиная с 2024 г., с использованием тех же самых учётных протоколов.

Мы обнаружили, что 75\% всех степных орлов, учтённых на пролёте нах Эйлатом в 2010-х гг., оказамись взрослыми половозрелыми особями, которые, по-видимому, имеют более высокий показатель выживаемости. В то время как большинство орлов, зимуюших в Аругих местах к северу от Эйлата и на Аравийском полуострове - это молодые особи (McGrady, Meyburg, 2018; Meyburg et al., 2003), а потому снижение их численности может быть выражено резче, чем у взрослых орлов, как и предполагаи Б. Мейбург (Meyburg et al., 2003).

Тот факт, что 75\% особей, мия которых была опрелелена возрастная группа в 2010-е годы, оказамись половозрелыми означает, что зимовкой в Африке и миграционным коридором, идушим через "бутылочное горлышко" в Эйлате, пользуется основная гнездяшаяся группировка вила (репродуктивное янро вида). Это хорошо согласуется с Аанными о том, что молодые орлы держатся ближе к гнездо-
The fact that $75 \%$ of the aged individuals in the 2010's count were adults implies that the Eilat bottleneck and Africa are home for a main breeding cohort of the species. This data corresponds well with findings that younger eagles stay closer to the breeding range in Central Asia or migrate just "half the way" to Arabia (McGrady, Meyburg, 2018). The second half of February is the main time of passage for adult eagles in Eilat. This knowledge allows us and other nature conservation agencies to intensify conservation efforts to safeguard the flyways during this crucial time of year. The actions that should be considered in this period are shutting down wind turbines (in Egypt and Jordan), a hunting ban and providing safe drinking and feeding stations (clean carcasses) on their route.

\section{Acknowledgments}

We thank our global team of survey counters; you are much appreciated but too numerous to name here. Thanks to Charly Rubinet and Margaux Ruiz who helped writing the counting protocol. Special thanks to IBRCE team Libby Yeframov and Tzadok Zemach for taking care of the volunteer counters and managing the count stations and to Michelle Fizni for the English proofing.

\section{References}

Besten J.W.D. Migration of Steppe Eagles Aquila nipalensis and other raptors along the Himalayas past Dharamsala, India, in autumn 2001 and spring 2002. - Forktail. 2004. 20: 9-13. URL: https://orientalbirdclub.org/wp-content/ uploads/2012/09/Besten-Eagles.pdf Date accessed 07.10.2018.

BirdLife International. Aquila nipalensis (amended version of 2016 assessment). The IUCN Red List of Threatened Species 2017: e.T22696038A118576408. DOI: $10.2305 /$ IUCN. UK. 2017-3.RLTS.T22696038A 118576408. en. URL: https://www.iucnredlist.org/species/22696038/118576408 Downloaded on 07.10.2018.

Bohra D.L., Vyas S. Human Impact on Steppe Eagle and other Birds of Prey in North-West Rajasthan, India. - Raptors Conservation. 2018. Suppl. 1: 100-101. URL: http://docs.sibecocenter.ru/programs/raptors/RC-s1/RC-s1_ProcBohra-100-101.pdf Date accessed 07.10.2018.

Forsman $D$. Flight identification of raptors of Europe and the Middle East. A handbook of field identification. T \& D Poyser, 1999.: 1-608.

Goroshko O.A. Population Status and Conservation Issues of Steppe Eagle in the Daurian Steppe, Russia. - Raptors Conservation. 2018. Suppl. 1: 89-91. URL: http://docs.sibecocenter.ru/programs/raptors/RC-s1/RC-s1_ProcGoroshko-89-91.pdf Date accessed 07.10.2018. 
вому ареалу в Центральной Азии или же совершают миграцию мишь "на полпути" на Аравийский полуостров (McGrady, Meyburg, 2018). Вторая половина февраля - основное время пролёта взрослых орлов через Эйлат. Знание об этом позвомяет нам и Аругим природоохранным организациям усилить меры по обеспечению безопасного пролёта в самое критичное Аля этого время года. В это время следует останавливать ветряные электростанции (в Египте и Иордании), накиадывать запрет на охоту и обеспечивать орлов безопасными водопоями и подкормочными станциями (с останками копытных, не содержаших опасных вешеств) на их пути миграции.

\section{Благодарности}

Мы благодарим всю нашу интернациональную команду, проводившую наблюдения - слишком многочисленную, чтобы всех назвать поимённо, но очень высоко ценимую нами. Спасибо Чарли Рубинет (Charly Rubinet) и Марго Руис (Margaux Ruiz), которые помогли написать счётный протокол. Особое спасибо команде IBRCE за заботу об учётчиках-волонтёрах и обеспечение учётных станций и Мишель Физни (Michelle Fizni) за редакцию английской версии статьи.

Эйлатские горы "бутылочное горлышко" на весенней миграции хищных птиц. Фото Э. Николенко.

Eilat Mountains is bottleneck of spring migration of raptors. Photo by E. Nikolenko.

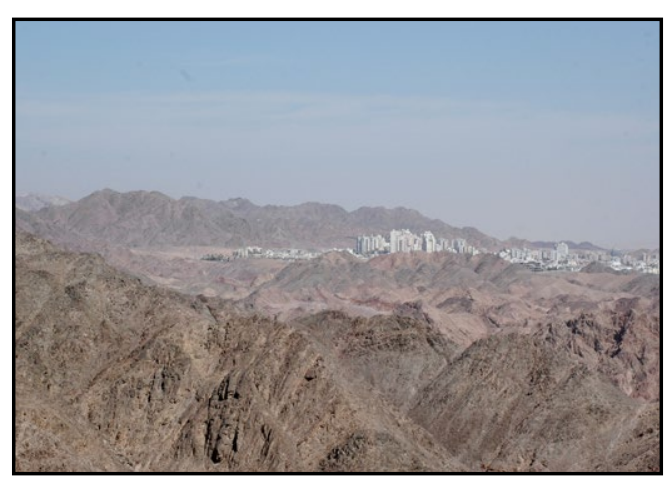

Hackshaw A., Kirkwood A. Interpreting and reporting clinical trials with results of borderline significance. - Bmj. 2011. 343: d3340. DOI: 10.1136/bmj.d3340 URL: https://www.bmj. com/content/343/bmj.d3340 Date accessed 07.10.2018.

IBM Corp. Released 2015. IBM SPSS Statistics for Windows, Version 23.0. Armonk, NY: IBM Corp.

Karyakin I.V. Review of the Modern Population Status of the Steppe Eagle in the World and in Russia. - Raptors Conservation. 2013. 26: 2243. URL: http://rrrcn.ru/en/archives/19580 Date accessed 07.10.2018.

Karyakin I.V. Status of the Steppe Eagle in the World: "White Spots" in Distribution, Population Numbers, Ecology and Threats. - Raptors Conservation. 2018. Suppl. 1: 81-84. URL: http://
docs.sibecocenter.ru/programs/raptors/RC-s1/ RC-s1_Proc-Karyakin-81-84.pdf Date accessed 07.10.2018.

Karyakin I.V., Nikolenko E.G., Shnayder E.P., Horváth M., Prommer M., Juhász T., Bartoszuk K., Zinevich L.S. Direction, Nature and Timing of Migration of the Steppe Eagles from the VolgaUral and Altai-Sayan Regions (Russia) on Data of the GSM/GPS and Argos/GPS-telemetry. - Raptors Conservation. 2018. Suppl. 1: 96-99. URL: http://docs.sibecocenter.ru/programs/raptors/ RC-s1/RC-s1_Proc-Karyakin-etal-96-99.pdf Date accessed 07.10.2018.

Kerlinger $P$. Flight strategies of migrating hawks. University of Chicago Press, Chicago, USA, 1989: 1-392.

McGrady M.J., Meyburg B.-U. Annual Movements of Two Steppe Eagles, and Their Use of Rubbish Dumps in Arabia During the Winter. - Raptors Conservation. 2018. 2018. Suppl. 1: 95. URL: http://docs.sibecocenter.ru/programs/ raptors/RC-s1/RC-s1_ProcMcGrady-95.pdf Date accessed 07.10.2018.

Meyburg B., Patrick P., Meyburg C. Migration routes of Steppe Eagles between Asia and Africa: a study by means of satellite telemetry. - The Condor. 2003. 105(2): 219-227. DOI: 10.1650/0010-5422(2003)105[0219:MROSEB] 2.0.CO;2

Oaks J.L., Gilbert M., Virani M., Watson R.T., Meteyer C.U., Rideout B., Shivaprasad H.L., Ahmed S., Chaudhry M.J.I., Arshad M., Mahmood S., Ali A. Khan A.A. Diclofenac residues as the cause of vulture population declines in Pakistan. - Nature. 2004. 427(6975): 630-633. DOI: 10.1038/nature02317 URL: https://www.researchgate.net/ publication/8902065 Date accessed 07.10.2018.

Shirihai H., Alon D., Yosef R., Kirwan G.P., Spaar R. Raptor migration in Israel and the Middle East: a summary of 30 years of field research. International Birding \& Research Center in Eilat, 2000: 1-191.

Shirihai H., Christie D.A. Raptor migration at Eilat. - British Birds. 1992. 85(4): 141-186. URL: https://www.birds.org.il/Data/Docs/Species\%20Data/RaptormigrationinEilat-HadoramShirihai_1591371027.pdf Date accessed 07.10.2018.

Subedi T.R. East to west migration of Steppe Eagle (Aquila nipalensis) and other raptors in Nepal; abundance, timing and age class determination. NOU Research Report No. 1. Nepalese Ornithological Union, Kathmandu, Nepal, 2015: 1-38. DOI: 10.13140/RG.2.2.26813.46565 URL: https://www.researchgate.net/publication/313256156 Date accessed 07.10.2018.

Zduniak P., Yosef R., Sparks T.H., Smith H. and Tryjanowski $P$. Rapid advances in the timing of the spring passage migration through Israel of the Steppe Eagle Aquila nipalensis. - Climate Research. 2010. 42: 217-222. DOI: 10.3354/ cr00900 URL: https://www.int-res.com/articles/cr2010/42/c042p217.pdf Date accessed 07.10 .2018 . 